\title{
Castleman's disease with autoimmune haemolytic anaemia, subfertility and meningomyelocele
}

\author{
N Weerasuriya', L M Ranasinghe ${ }^{2}, 1 \mathrm{~S}$ Wijesiriwardene ${ }^{3}$ and D J S Fernando
}

\section{Introduction}

Castleman's disease (CD) (angiofollicular lymph node hyperplasia) was first described in 1936 (1). It is a rare disease of unknown aetiology affecting the lymph nodes. $\mathrm{CD}$ consists of two basic histological types: hyaline-vascular (HV) and plasma-cell (PC), and a mixed type called hyaline-vascular plasma cell type (HV-CV) (2). Clinically, it presents as an indolent disease confined to a single site (unicentric) or less commonly as a more generalised lymphadenopathy (multicentric), accompanied by constitutional symptoms, acute phase response, organomegaly and potential for malignancy. Anaemia is common but usually mild to moderate, normochromic and normocytic (3). Bone marrow cellularity and the myeloid/erythroid ratio $(\mathrm{M} / \mathrm{E})$ are normal (3).

Haemolytic anaemia as the presenting feature of CD has been described only twice before $(4,3)$. We report a case of CD with autoimmune haemolytic anaemia, subfertility, subsequent conception and delivery of a baby with a meningomyelocele.

\section{Clinical presentation}

A 30-year old woman was admitted with progressive breathlessness, malaise and weakness for one month. She was anaemic ( $\mathrm{Hb} 3.4 \mathrm{~g} / \mathrm{dl}$ ) and had enlarged supraclavicular and left axillary lymph nodes. The lymph nodes were non-tender, smooth and 2 to $4 \mathrm{~cm}$ long. Further clinical examination was unremarkable except for a $5 \mathrm{~cm}$ hepatomegaly and $4 \mathrm{~cm}$ splenomegaly.

The ESR was $174 \mathrm{~mm}$, but the $\mathrm{C}$-reactive protein was $<6 \mathrm{mg} / 1$. Antinuclear factor was negative. The white cell count was 3800 x 1071 with a normal differential count. The blood picture showed polychromasia and spherocytes. The reticulocyte count was $5.6 \%$. The direct Coomb's test was positive, confirming autoimmune haemolytic anaemia. Bone marrow biopsy showed an inversed M/E of 1:2 with hyperplastic and megaloblastic erythropoiesis, and normal granule- and thrombopoiesis. There was no evidence of non-haemopoietic cell infiltrate, and the plasma cells and lymphocytes were seen in normal numbers. The chest xray

'Registrar, University Medical Unit, "Senlor Lecturers in Pathology and Haematology, and ^Professor of Medicine, Faculty of Medical Sciences, University of Sri Jayewardenepura. (Revised version accepted 25 August 2001. Corresponding author NW, E-mail: irw@mail.ewisl.net) 
and serum protein electrophoresis were normal. Ultrasound scan of the abdomen confirmed hepatosplenomegaly.

Excision biopsy of the enlarged lymph nodes showed lymphoid follicular hyperplasia. The interfollicular area was densely infiltrated by plasma cells. Prominent perinodal fibrosis was seen. There was no evidence of a neoplastic lesion. The histology confirmed a diagnosis of plasma-cell type Castleman's disease.

Although the treatment of unicentric $\mathrm{CD}$ is excision of the offending lymph nodes, treatment of multicentric $\mathrm{CD}$ is unclear. Systemic therapy with steroids alone or incombination with chemotherapeutic agents and radiotherapy has met with varied success $(3,6,7,8)$.

In consultation with an oncologist the patient was managed with prednisolone, vitamins, iron and folate supplements. Starting prednisolone at $40 \mathrm{mg} /$ day for one month, the dose was tapered to a maintenance dose of 10 $\mathrm{mg} /$ day. She was followed up monthly at the clinic and the haemoglobin remained stable at 9 to $10 \mathrm{~g} / \mathrm{dl}$. At 6 months she became pregnant for the first time after four years of marriage. Regular assessment in a clinic with a consultant obstetrician was arranged from the start of pregnancy. The maintenance dose of prednisolone was continued. Her condition was stable till the $28^{\prime \prime}$ week of amenorrhoea. Thereafter the ESR started rising and she became increasingly anaemic. The fetal growth was assessed to be normal. She was admitted to the ward during the $28^{\text {th }}$ and the $32^{\text {nd }}$ weeks for blood transfusions. In the $34^{*}$ week the baby was delivered by caesarian section because of preterm labour and meconium stained liqor, but it was found to have a meningomyelocele and paraplegia.

\section{Discussion}

CD is known to cause reversible subfertility (9). This patient has had regular sexual intercourse without contraception for four years. She was treated with corticosteroids after excision of some enlarged lymphnodes, following which the disease became quiescent for several months. She conceived during this time.

Folate deficiency is known to cause neural tube defects. The patient was on folate supplements for 6 months before conception and the haemoglobin was stable. Prednisolone could not be discontinued considering her clinical status. In addition, there is no proven teratogenic effect of corticosteroids (10). CD has not previously been associated with fetal neural tube defects. Since it is a rare disorder, and pregnant women with $\mathrm{CD}$ are rarer, this may be the first case of $\mathrm{CD}$ associated with fetal meningomyelocele.

\section{References}

1. Castleman B, Iverson L, Menendez V. Localized mediastinal lymph-node hyperplasia resembling thymoma. Cancer 1956; 9: 822-30.

2. Keller AR, Hochholzer L, Castleman B. Hyaline-vascular and plasma-cell types of giant lymph node hyperplasia of the mediastinum and other locations. Cancer 1972; 29: 670-83.

3. Browne WB, Lewis JJ, Filippa DA, Niesvizky R, Brooks AD, Burt ME, Brennan MF. The management of unicentric and multicentric Castleman's Disease. Cancer 1999; 85: 706-17.

4. Ciberato NL, Bolatti Q, Chiofalo F, Fillipino M. Autoimmune haemolytic anaemia in multicentric Castleman's disease. Clinical Rheumatology 1997; 16: 87-92.

5. Rojas R, Martin C, Roman J, Garcia JM, Machal T, Toress A. Autoimmune haemolytic anaemia presenting 9 years prior to Castleman's disease. British Journal of Haematology 1994; 86: 431-2.

6. McCarty MI, Vuklia SJ, Banks PM, Weiss RB. Angiofollicular lymphinode hyperplasia (Castleman's disease). Cancer Treatment Review 1995; 21: 291-310.

7. Kasantikul V, Panyavoravut V, Benjaavongkulchai S, Panichabhongse V. Castleman's disease - a clinico-pathological study of 12 cases. Journal of the Medical Association of Thailand 1997; 80: 195-201.

8. Marti S, Pahissa A, Guardia J, Moragas A, Bacardi R.Multicentric giant follicular lymph node hyperplasia favourable to radiotherapy. Cancer 1983; 5: 808-10.

9. Adamson DI. Currie JM. Reversible infertility and Castleman's disease. Clinical Laboratory Haematology 1991; 13: 349-50.

10. Fraser FC, Sajoo A. Teratogenic potential of corticosteroids in humans. Teratology 1995; 51:45-6. 